\title{
Redesigning services for the management of vitreomacular traction and macular hole
}

W Amoaku, P Cackett, A Tyagi, U Mahmood, J Nosek, G Mennie and N Rumney

Eye (2014) 28, 1150; doi:10.1038/eye.2014.194

Correction to: Eye (2014) 28, S1-S10; doi:10.1038/eye.2014.125

Since the publication of the above article, it has been noted that the incorrect Creative Commons License logo and text were given. The details are given below. In addition, the Open logo was missing from above the article title on the first page.

The typesetters would like to apologise for this error.

(c) (1) () $\odot$ This work is licensed under a Creative Commons Attribution-NonCommercial-NoDerivs cc) 3.0 Unported License. The images or other third party material in this article are included in the article's Creative Commons license, unless indicated otherwise in the credit line; if the material is not included under the Creative Commons license, users will need to obtain permission from the license holder to reproduce the material. To view a copy of this license, visit http://creativecommons. org/licenses/by-nc-nd/3.0/ 